\title{
Capability of Updating the List of Permanent Voters by Pekanbaru Election Commission During 2019 Election
}

\author{
Rury Febrina ${ }^{1}$, Friska Amanda ${ }^{2}$, Jastika Nofriyanti ${ }^{3}$, Juni Yulfiyanti \\ Hutabarat ${ }^{4}$ \\ ${ }^{1}$ Universitas Riau \\ $2,3,4,5,6$, Universitas Lancang Kuning, Riau \\ ruri.febrina@unri.ac.id
}

\begin{abstract}
This article discusses the problem of double voter lists in Pekanbaru. General Elections Commission (KPU) Pekanbaru set 3.62 Million Final Voter List (DPT), and Election Supervisory Agency (Bawaslu) found 1,956 double DPT. The problem of double DPT is seen from the aspect of updating data from the KPU Pekanbaru in the process of determining the number of DPT through stages of matching and research (coklit). This study uses descriptive qualitative methods with informants determined by researchers. The informant for this research is KPU Pekanbaru. The data obtained have been analyzed with an ethical and emic approach to reveal that the double DPT was caused by the coklit process, which was not optimally conducted by Pekanbaru's KPU. The coklit process was hampered because voters were not at their place, so the KPU only relied on data from the neighbourhood (RT).
\end{abstract}

Keywords: Elections; voter; DPT

\section{Introduction}

Indonesia is a democratic country which organizes general elections once in five years. General Election is a process of selecting people's representatives starting from the Executive Position, namely the Head of State or President, the Legislative Position, the House of Representatives (DPR), the Regional Representative Council (DPD), the Regional Head or Governor, the Regent to the lowest level of the Village Head. The holding of elections is never independent of citizens because it is a constitutional right of citizens both to vote and be elected (Nugroho, W. 2016)

Results from the examination of the Election Supervisory Agency (Bawaslu) determined by the KPU, it was determined that 3.62 million voters registered in the DPT, in the analysis of Election Supervisory Agency of Pekanbaru found at least 1,956 double DPT (source: Bawaslu Pekanbaru)

Constraints experienced by KPU in election process were not found by the voters when the PPDP visited the voters' place. However, the data collection officers continued to visit the voters' place for several days but still did not get the data from them, so the PPDP decided to take data from the local RT.

An institution that is given the authority to hold general election activities is the General Election Commissiuon (KPU) stated in Law No. 22 of 2007. The jobs for KPU start from planning, preparing to announce the election results. Overall, KPU has levels ranging from KPU Central, KPU Provincial and KPU Regency (Yamin, M. H. (2013).

One of the problems that happen in every election is voter lists. The final series of the voter update process is crucial for the preparation for the final voter list (DPT) because it includes population issues and their data are often inaccurate. It is inseparable from the insistence of various parties, especially the Election Supervisory Agency (Bawaslu) and Political Parties participating in the election so that KPU can resolve various issues concerning DPT. In practice, related to the handling of this 
voter data, that is the Update of Final Voter List Results of Phase 3 Improvement (DPThp 3) conducted by the KPU, was only completed on April $8^{\text {th }}, 2019,9$ days before D-day voting. It means 21 days back from the schedule set by the KPU, which is March 19 $9^{\text {th }}, 2019$ (ADE, F. (2018)).

Some parties stated that the main obstacle for the delay was that KPU had difficulty in sorting the Voter Data. It comprehensively in synergy with the Voter Data in the Ministry of Home Affairs, so there were still errors in the form of double registered, registered deceased, and nonupdating of voters who moved domicile. Bawaslu also stated that the KPU's Data Information System often had errors which disrupted the uploading process and downloading data. The next problem is that foreigners who entry the DPT do not have an electronic KTP but have an electronic KTP record. So what is being checked is a certificate of recording an electronic KTP, not an electronic KTP. It happened because the research conducted by KPU was not entirely done factually from house to house (Haboddin, M. (2016))

Voter data sourced from the KPU is still a problem because there is no improvement for the voter list made by the Voter Data Updating Officer (PPDP). Therefore, PPDP officers have an essential role in the preparing voter list data process. If the coklit officers does not have integrity, violations or irregularities in the coklit process can occur. Coklit is an activity carried out by PPDP officials by visiting voters directly from door to door carefully match existing voter data with real conditions on the ground (ADE, F. (2018)).

In this case, Pekanbaru is one of the cities in Riau Province that has held elections. The tasks of KPUD Pekanbaru is to manage, compile and submit permanent voter list data. It is an obstacle and challenge for the Election Commission in Pekanbaru in resolving these problems. The Election Commission of Pekanbaru stipulates:

Table 1

The number of 2019 Final Voter Lists (DPT) in Pekanbaru

\begin{tabular}{ll}
\hline \multicolumn{1}{c}{ Final Voter Lists } & \multicolumn{1}{c}{ Number of People } \\
\hline Male voters & 1.891 .490 people \\
Female voters & 1.832 .074 people \\
TPS & 17.440 \\
Village office & 1.859 \\
Sub-district & 166 \\
\hline Total & 3.743.029 people \\
\hline
\end{tabular}

DPT can be said to be double if it fulfils 4 criteria, namely if: full name, gender, place of birth date and address is similar. From a total of 3,743,029 people, 1,956 double DPTs cannot use their voting rights. Therefore, it is necessary to conduct an indepth analysis study on the determination of voter data.

This study examines the capability of updating the DPT by the Pekanbaru Election Commission ahead of the 2019 elections. As a means of democracy, elections provide an opportunity for the people to vote and give legitimacy to their representatives who sit in the government. The problem is the emergence of multiple voter lists due to the absence of an exact matching and research (coklit) process and the non-integrity voter data updating committee. Through the concept of elections and political participation using qualitative methodologies, this research explains the problem of updating the DPT 
by the Election Commission which is still procedural so that many people cannot use their right to vote. Therefore, updating voter data needs to be done comprehensively and simultaneously.

\section{Theoretical Perspectives}

\subsection{Research Method}

This study uses qualitative methods with the technique of drawing informants prioritizing the quality of data obtained through the delivery of informants related to the research problem. To obtain the right data, researchers used several data collection techniques, namely: in-depth interviews (in-depth interviews) and documentation, collecting data, and making conclusions so it is easily to be understood by themselves and others (Yandra 2017: 9). All data obtained will be analyzed using qualitative methods through interpretation. This process clarifies data into two parts, namely ethical data (from theory) and emic data (from field findings). Furthermore, the process of reducing the results of data analysis can be measured and be able to be scientifically justified even as new findings in developing the theory of political participation.

\subsection{Literature Review}

Reviewing the essence of elections in a democratic country, it is necessary to explain the election by experts, including, according to (Ramlan, 1992: 181) Election is defined as "the mechanism of selection and delegation or the transfer of sovereignty to people or parties that are trusted. According to Harris G. Warren and friends, the election is: "Elections are the accusations when citizens choose their officials and vote, what they want the government to do. These decisions citizens determine what rights they want to have and keep."

1) According to Ali Moertopo the understanding of the Election is as follows: "Basically, elections are a means available to the people to run their sovereignty following the principles set out in the Preamble to the 1945 Constitution. The election itself is a Democratic Institute which elects members of the people's representatives. In MPR, DPR, DPRD, who in turn are tasked with working together with the government, determining the politics and running of the state government."

2) According to Suryo Untoro "That the General Election (from now on referred to as the Election) is an election conducted by Indonesian citizens who have the right to vote, to elect their representatives who sit in the House of Representatives, namely the House of Representatives (DPR), the Council Level I and Level II Regional Representatives (DPRD I and DPRD II)"

3) According to Morissan (2005: 17), General election is a way or means to find out the people's wishes regarding the direction and policies of the country going forward. There are at least three types of general election objectives, namely enabling the transfer of government in a safe and orderly manner to carry out people's sovereignty in the context of implementing the rights of citizens.

From some of the definitions above, it can be concluded that the notion of elections as an essential means in the life of a country. It adheres to the principle of democracy, which provides an opportunity for political participation for citizens to choose their representatives who will voice and channel their aspirations. However, this research explains that elections are an integral part of democracy and updating data is the initial process in elections.

\section{Results and Discussion}

\subsection{Voter Data Findings Ahead of the 2019 Elections in Pekanbaru}

The problem with the holding of 2019 simultaneous elections is the KPU have difficulty in sorting the voter data comprehensively so that there are still errors in the form of double registered, registered dead, and not updated voters who moved domicile. 
The process of updating data from door to door and matching data from Disdukcapil update through the application is a step in the process of forming DP4.

For double-listed issues, KPU said that voter data could be assumed to be double if it meets 4 criteria, namely full name, gender, place of birth, and address is similar.

The cause of registration deceased was due to the heirs who did not take care of the death certificate at the Civil Registry Office (Disdukcapil) so that the voters who had died were still included in the DPT. Although the KPU and Disdukcapil knew that the person had died, the KPU and Disdukcapil did not dare to take action deleting data of the deceased voter from the DPT.

The Voter Registration Renewal Committee (PPDP) is one of the processes of collecting voter register data whose task is to survey residents' homes. However, there are obstacles such as the house being empty, the owner of the house who does not respond, the fence is locked, the house is guarded by pets, and many residents do not report they have lived in the area so that the local RT does not know when asked by PPDP officers.

KPU has a Voter Data System Application (SIDALIH), the public can also check the data whether the name has been registered or not, and if there is a misspelling on the name. But this application is still not widely known by the public because of a lack of concern and curiosity in the process of updating this data. Still, one of the difficulties from this application is not be able to fulfil all requests because of a hacker who interferes with the voter list processing system.

Therefore, KPUD Riau is immediately made an ongoing effort in the process of updating the data as an effort to save the voting rights of citizens in problematic areas to continue participating (Yandra, 2017). By using descriptive qualitative methods, as well as the concept of political interest theory in local elections and regional elections and data analysis through ethical and emic interpretation then elaborated in governance studies by the discussion under study, the results of this study indicate, despite the efforts made by KPUD

Riau.

Table of Voter Data Movement in Pekanbaru in 2019

\begin{tabular}{|c|c|c|c|c|c|c|c|c|c|c|c|c|}
\hline \multirow[b]{2}{*}{ Regency/City } & \multirow{2}{*}{$\begin{array}{c}\text { Total of } \\
\text { Sub- } \\
\text { district }\end{array}$} & \multirow{2}{*}{$\begin{array}{c}\text { Total of } \\
\text { Village/village } \\
\text { office }\end{array}$} & \multicolumn{4}{|c|}{ Total of TPS } & \multicolumn{5}{|c|}{ Total of Voters } & \multirow[b]{2}{*}{ KET } \\
\hline & & & DPS & DPT & $\begin{array}{c}\text { DPTHP } \\
-1\end{array}$ & $\begin{array}{c}\text { DPTHP- } \\
2\end{array}$ & DP4 & DPS & DPT & $\begin{array}{c}\text { DPTHP- } \\
1\end{array}$ & DPTHP-2 & \\
\hline Pekanbaru & 12 & 83 & 2,422 & 2,437 & 2,437 & 2,448 & 622,830 & 482,001 & 490,820 & 489,634 & 507,213 & - \\
\hline
\end{tabular}

\subsection{Impact of Multiple Voter Findings}

The impact of the findings on multiple voters included a large number of people who could not use their voting rights to vote in the 2019 election because the KPU had problems in sorting voter data and the KPU was not optimally using DP4 from the Ministry of Home Affairs. The main task of the Ministry of Home Affairs in compiling the voter list is to provide DP4 and assist the KPU in updating the data.
Furthermore, many people complained to the polling station in their area of residence and the KPU office because they could not use their voting rights during the election. The enthusiasm of the people is very high to participate in the 2019 election, but the lack of public awareness in checking the data so that there are problems such as double voter lists. However, KPU has facilitated the existence of a Voter Data System (SIDALIH), but the lack of public 
awareness in the facilities provided by the KPU.

Another impact of this problem is that if the DPT has a problem, it will reduce public trust in the KPU as the organizer of the election. With so many problems in the current elections, it is feared that in the future, the enthusiasm of the people to become less will be reduced to participate in voting.

\subsection{Accurate Determination Mechanism to avoid Multiple Voter Lists}

To succeed the election requires good cooperation between the community and the organizers so that various obstacles and problems do not occur. With the problems and impacts that have occurred during the holding of the 2019 elections, it is necessary to have a more systematic mechanism and KPUD Pekanbaru can carry out its duties optimally and following a predetermined time.

The need for good cooperation between the KPUD Pekanbaru, Disdukcapil, and the Ministry of Home Affairs, in the process of updating data and strengthening between sectors which is more intensive. No further issues with updating data, as a mistake previously in the form of double registration, registered dead and not updated voters moving place, should be minimized. The need to strengthen intensive cooperation so that the issue of data updating is not only about the KPU's problems, but how the future of shared understanding regarding citizens' voting rights is the responsibility of the government.

The community also has a vital role in the process of organizing elections. One of its roles is as a voter using its voting rights. Still, there is a need for awareness and concern from the community to help the election organizers by checking, when the Election Commission Pekanbaru has issued a DPS, if a discrepancy occurs. The community should report to the RT so that the data can be improved by the City Election Commission Pekanbaru.

\section{Conclusion}

PPDP officers have done the coklit process but are still experiencing difficulties in meeting voters at their residence. This obstacle was overcome by the KPUD Pekanbaru by relying on data from the local RT. This resulted in a double DPT due to differences in data from disdukcapil with real data in the field. Election Commission Pekanbaru can not do much because of time constraints in the process of research with a huge number of DPT.

This is an evaluation for the KPUD Pekanbaru to improve the DPT data update process in the next election. Because the double DPT will have an impact on the quality of elections and democracy in Indonesia, we suggest that the coklit process is carried out in a period of periodic and long periods so that the validity of DPT can be done well and maximally.

In most democracies, elections are seen as symbols and benchmarks of democracy. Elections that are open, free to say and free to reflect democracy, although not so accurate. In the 2019 General Election, various problems arose, namely errors in the form of double registration, registration of deceased persons, and non-updating of voters who moved. These problems are not problems that have just occurred, and due to many factors not supporting the 2019 election process. To succeed in this election, it cannot be done by the election organizers alone, but there needs to be awareness and cooperation from the public so that the preparation process ahead of the election can proceed smoothly and there are no obstacles.

\section{References}

ADE, F. (2018). Malpraktik Penyelenggara Dalam Pelaksanaan Pencocokan dan Penelitian (Coklit) Daftar Pemilih Pada Pemilihan Kepala 
Daerah dan Wakil Kepala Daerah di Kota Solok Tahun 2015 (Doctoral dissertation, Universitas Andalas).

Arrsa, R. C. (2016). Pemilu Serentak dan Masa Depan Konsolidasi Demokrasi. Jurnal Konstitusi, 11(3), 515-537.

Ekatrin, M. S. (2016). Perbandingan Mekanisme Pendaftaran Wajib Pajak dan Pelaporan Surat Pemberitahuan Pajak Secara Manual dengan Secara Elektronik (E-Filing) pada Kantor Pelayanan Pajak Pratama Lubuk Pakam.

Haboddin, M. (2016). Pemilu dan Parpol di Indonesia. Universitas Brawijaya Press.

Nugroho, W. (2016). Politik Hukum Pasca Putusan Mahkamah Konstitusi atas Pelaksanaan Pemilu dan Pemilukada di Indonesia. Jurnal Konstitusi, 13(3), 480-502.

Sardini, N. H. (2011). Restorasi penyelenggaraan pemilu di Indonesia. Fajar Media Press.

Yamin, M. H. (2013). Netralitas Pegawai Negeri Sipil dalam Pemilihan Umum Kepala Daerah di Kabupaten
Takalar. Makasar: Universitas Hasanuddin.

Yandra, A. (2017). Fisibilitas Pilkada Serentak Tahap II Kota Pekanbaru Pasca Permendagri No 18 Tahun 2015. Jurnal Niara, 9(2), 62-74.

Yandra, A. (2017). Penyelamatan Hak Pilih Warga Perbatasan Jelang Pilkada. POLITIK, 13(1). 